\title{
Sodium/Calcium Exchange Modulates Intracellular Calcium Overload during Posthypoxic Reoxygenation in Mammalian Working Myocardium

\author{
Evidence from Aequorin-loaded Ferret Ventricular Muscles
}

\author{
Yasuki Kihara, Shigetake Sasayama, Moriaki Inoko, and James P. Morgan \\ The Second Department of Internal Medicine, Toyama Medical and Pharmaceutical University, School of Medicine, Toyama 930, \\ Japan; and Harvard-Thorndike Laboratory, Beth Israel Hospital and Harvard Medical School, Boston, Massachusetts 02215
}

\begin{abstract}
We tested the hypothesis that the intracellular $\mathrm{Ca}^{2+}$ overload of ventricular myocardium during the period of posthypoxic reoxygenation is mediated by transsarcolemmal $\mathrm{Ca}^{2+}$ influx via $\mathrm{Na}^{+} / \mathrm{Ca}^{2+}$ exchange. In aequorin-loaded, ferret right ventricular papillary muscles, blockers of the sarcolemmal and the sarcoplasmic reticulum $\mathrm{Ca}^{2+}$ channels, slowed the $\mathrm{Ca}_{\mathrm{i}}^{2+}$ transient, producing a convex ascent during membrane depolarization, followed by a concave descent during repolarization. The magnitude of the $\mathrm{Ca}_{\mathrm{i}}^{2+}$ transient was affected by changes in the membrane potential, $\mathrm{Na}_{\mathrm{i}}^{+}, \mathrm{Na}_{0}^{+}$, and $\mathrm{Ca}_{0}^{2+}$, and was blocked by $\mathrm{Ni}^{2+}$, or dichlorbenzamil. The calculated $\mathrm{Na}^{+} / \mathrm{Ca}^{2+}$ exchange current was in the reverse mode $\left(\mathrm{Ca}^{2+}\right.$ influx) during the ascending phase of the $\mathrm{Ca}_{i}^{2+}$ transient, and was abruptly switched to the forward mode $\left(\mathrm{Ca}^{2+}\right.$ efflux $)$ at repolarization, matching the time course of the $\mathrm{Ca}_{\mathbf{i}}^{2+}$ transient. During hypoxic superfusion, the $\mathrm{Ca}_{\mathrm{i}}^{2+}$ transient was abbreviated, which was associated with a shorter action potential duration. In contrast, immediately after reoxygenation, the $\mathrm{Ca}_{i}^{2+}$ transient increased to a level greater than that of the control, even though the action potential remained abbreviated. This is the first demonstration on a beat-to-beat basis that, during reoxygenation, $\mathrm{Ca}^{2+}$ influx via $\mathrm{Na}^{+} / \mathrm{Ca}^{2+}$ exchange is augmented and transports a significant amount of $\mathrm{Ca}^{2+}$ into the ventricular myocardial cell. The activation of the exchanger at the time of reoxygenation appears to be mediated by $\mathrm{Na}_{\mathbf{i}}^{+}$accumulation, which occurs during hypoxia. (J. Clin. Invest. 1994. 93:1275-1284.) Key words: aequorin $\bullet$ calcium $\cdot$ ferret $\cdot \mathrm{Na}^{+} / \mathrm{Ca}^{2+}$ exchange $\cdot$ reperfusion
\end{abstract}

\section{Introduction}

Calcium might play a crucial role in the myocardial cell injury that occurs during postischemic reperfusion. Previous work has shown that intracellular calcium $\left(\mathrm{Ca}_{\mathrm{i}}^{2+}\right)$ of the myocardial cell rapidly increased during the early phase of global ischemia (1-4). The $\mathrm{Ca}_{i}^{2+}$ subsequently decreased during reperfusion if the duration of ischemia was limited to several minutes (1-4).

Dr. Kihara's and Dr. Sasayama's current address is Third Division, Department of Internal Medicine, Faculty of Medicine, Kyoto University, Kyoto 606, Japan.

Address correspondence to Dr. James P. Morgan, Cardiovascular Division, Beth Israel Hospital, 330 Brookline Avenue, Boston, MA 02215 .

Received for publication 4 April 1992 and in revised form 18 October 1993.

J. Clin. Invest.

(C) The American Society for Clinical Investigation, Inc.

$0021-9738 / 94 / 03 / 1275 / 10 \quad \$ 2.00$

Volume 93, March 1994, 1275-1284
By contrast, when the ischemic period lasted longer than 20 min, the elevated level of $\mathrm{Ca}_{i}^{2+}$ further increased during the reperfusion period $(5,6)$, and was associated with delayed afterdepolarizations and arrhythmogenicity $(5,7)$. These findings suggested that $(a)$ the cellular mechanisms responsible for $\mathrm{Ca}_{\mathrm{i}}^{2+}$ accumulation during reperfusion are qualitatively different from those in acute ischemia and, $(b)$ the duration of the preceding ischemia is a crucial factor which determines the level of $\mathrm{Ca}_{i}^{2+}$ loading when the tissue is reperfused. The $\mathrm{Na}^{+} /$ $\mathrm{Ca}^{2+}$ exchange mechanism may be responsible for the $\mathrm{Ca}_{\mathrm{i}}^{2+}$ loading during reperfusion $(8,9)$ or reoxygenation $(10,11)$. However, there is no concrete evidence to support this hypothesis because of the difficulty of demonstrating the functional state of this exchanger in actively contracting preparations. Using aequorin-loaded, isolated myocardium from the ferret ventricle, we demonstrated that the $\mathrm{Ca}_{\mathrm{i}}^{2+}$ transient, under experimental conditions where it is governed primarily by transsarcolemmal $\mathrm{Ca}^{2+}$ influx via $\mathrm{Na}^{+} / \mathrm{Ca}^{2+}$ exchange, increased when the preparation was reoxygenated after hypoxia. This increase appears to be caused by time-dependent $\mathrm{Na}_{i}^{+}$accumulation during hypoxia. Our results suggest that reperfusion injury could be minimized by interventions that prevent intracellular $\mathrm{Na}^{+}\left(\mathrm{Na}_{\mathrm{i}}^{+}\right)$loading during ischemia.

\section{Methods}

Muscle preparation. Right ventricular papillary muscles $(<0.7 \mathrm{~mm}$ in external diameter) were isolated from 6-8-wk-old male ferrets and mounted as described previously (12). In the tissue bath, each muscle was electrically stimulated to contract isometrically at $0.20 \mathrm{~Hz}$; $30.0 \pm 0.2^{\circ} \mathrm{C}$. The superfusate was a bicarbonate-buffered physiological salt solution with the following composition (in $\mathrm{mM}$ ): $118 \mathrm{NaCl}, 4.7$ $\mathrm{KCl}, 1.2 \mathrm{KH}_{2} \mathrm{PO}_{4}, 1.2 \mathrm{MgCl}_{2}, 1.0 \mathrm{CaCl}_{2}, 23 \mathrm{NaHCO}_{3}$, and $5.5 \mathrm{dex}-$ trose. The solution was continuously bubbled with a gaseous mixture of $95 \% \mathrm{O}_{2} / 5 \% \mathrm{CO}_{2}$, and the $\mathrm{pH}$ was adjusted to $7.40 \pm 0.02$. During the run-in period, each muscle was gradually stretched to a length that produced the maximal tension development. To record the $\mathrm{Ca}_{\mathrm{i}}^{2+}$ transients, a bioluminescent protein, aequorin, was loaded into surface myocytes by means of the modified chemical procedure (macroinjection $[1,13]$ ) while the electrical stimulation was temporarily terminated and the superfusate replaced with a nominally $\mathrm{Ca}^{2+}$-free solution composed of (in $\mathrm{mM}$ ): $118 \mathrm{NaCl}, 4.7 \mathrm{KCl}, 1.2 \mathrm{KH}_{2} \mathrm{PO}_{4}, 5.0 \mathrm{MgCl}_{2}, 23$ $\mathrm{NaHCO}_{3}, 20$ dextrose, and 5.0 pyruvate; $\mathrm{pH} 7.30 \pm 0.02$ at $20^{\circ} \mathrm{C}(1)$. Subsequently, $\mathrm{Ca}^{2+}$ concentrations and temperature were increased in a stepwise fashion, and finally, the superfusate was replaced with the control solution. As reported previously, the loading procedure did not affect the pattern of tension traces either in amplitude or in time course in these muscles $(1,5)$.

Signal acquisition and analysis. The tissue bath was shielded from external light, and the aequorin luminescence was detected with a photomultiplier tube (R464, Hamamatsu Photonics, Hamamatsu, Japan). The membrane potential of the surface myocyte was recorded with microelectrodes. The glass micropipettes used for electrical recording were filled with $3 \mathrm{M} \mathrm{KCl}$ and had tip resistances of 15-25 M , as 
measured in the solution described above. During experiments, the position of the pipette was remotely controlled from outside the light shield by a three-dimensional aqua-purificate micromanipulator (WR88, Narishige Scientifics, Tokyo, Japan) while the action potential was continuously monitored on an oscilloscope (COM7061A, Kikusui Co., Yokohama, Japan). The aequorin light signal (anode current of the photomultiplier tube), isometric tension (measured by a BG-10 load cell, Kulite Semiconductor Products, Leonia, NJ), and the action potential were simultaneously recorded onto strip-chart paper and magnetic tape. At the end of the experiment, all aequorin activity remaining in the muscle was discharged by $4 \%$ Triton X-100 (Sigma Chemical Co., St. Louis, MO) perfusion in the presence of $20 \mathrm{mM} \mathrm{CaCl}_{2}$. A rate constant for aequorin consumption of $2.11 / \mathrm{s}$ was used for this integration (1). The normalized luminescence was referred to a calibration equation at $30^{\circ} \mathrm{C}(1)$ to estimate the absolute $\mathrm{Ca}_{i}^{2+}$. For presentation and subsequent analyses, the signal-to-noise ratio of aequorin signals was improved by a stimulus-triggered average process for 16-64 serial events with an off-line computer (7T18A, NEC-Sanei, Tokyo, Japan).

Isolation of $\mathrm{Na}^{+} / \mathrm{Ca}^{2+}$ exchanger-operated $\mathrm{Ca}_{i}^{2+}$ transients. After control records were obtained, the following pharmacological agents were added to the superfusate in a cumulative manner: $1 \times 10^{-5} \mathrm{M} \mathrm{DPI}$ 201-106 (Sandoz Ltd., Basel, Switzerland), $1 \times 10^{-5} \mathrm{M}$ ryanodine (Calbiochem Corp., La Jolla, CA), $3 \times 10^{-6} \mathrm{M}$ verapamil (Eisai Co., Tokyo), $1 \times 10^{-5} \mathrm{M}$ acetylstrophanthidin (Sigma Chemical Co.), and the $\mathrm{Ca}^{2+}$ concentration $\left(\mathrm{Ca}_{\mathrm{o}}^{2+}\right)$ increased to $4 \mathrm{mM}$. DPI 201-106 is a tetrodotoxin (TTX) ${ }^{1}$-sensitive $\mathrm{Na}^{+}$channel agonist that blocks the channel inactivation process and prolongs action potentials of the mammalian myocyte $(12,14,15)$. With this combination of drugs, $\mathrm{Ca}^{2+}$ release from the sarcoplasmic reticulum (SR), which predominantly regulates the $\mathrm{Ca}_{\mathrm{i}}^{2+}$ transient in normal ferret myocardium, and the transsarcolemmal $\mathrm{Ca}^{2+}$ influx via the $\mathrm{Ca}^{2+}$ channels are inhibited $(16,17)$. In contrast, with increases in $\mathrm{Na}^{+}$influx, $\mathrm{Ca}_{0}^{2+}$, and action potential duration, the $\mathrm{Ca}^{2+}$ influx through the reverse mode of the $\mathrm{Na}^{+} / \mathrm{Ca}^{2+}$ exchanger should be enhanced $(16,17)$. Under these pharmacological interventions, the preparation continued to contract with punctate electrical stimulation at the base (square wave pulse with $1 \mathrm{~ms}$ duration; amplitude $10 \%$ above the threshold). In the presence of TTX (Sigma Chemical Co.), $\mathrm{NiCl}_{2} \cdot 6 \mathrm{H}_{2} \mathrm{O}$ (Wako Pure Chemical Industries, Ltd., Osaka, Japan), or dichlorobenzamil (DCB; Merck Sharpe \& Dohme, Rahway, NJ), the electrical stimulation was maintained by increasing the amplitude of the pulses by $100 \%$.

Hypoxia and reoxygenation. Twenty minutes before induction of hypoxia, $5.5 \mathrm{mM}$ dextrose in the solution was replaced with equimolar sucrose (18). Then, hypoxia was induced by an abrupt change of solutions from one bubbled with a gaseous mixture of $95 \% \mathrm{O}_{2} / 5 \% \mathrm{CO}_{2}$ to one bubbled with $95 \% \mathrm{~N}_{2} / 5 \% \mathrm{CO}_{2}(18,19)$. No other conditions were altered, including the temperature and the $\mathrm{pH}$, during this exchange. After 20 min of hypoxia, reoxygenation was accomplished by switching these solutions back to the control.

Statistics. Data are presented as mean \pm SD. Comparisons were made between parameters under control, hypoxia, and reoxygenation by Student's $t$ test or by analysis of variance for repeated measures. Differences are considered significant at $P<0.05$.

\section{Results}

Evidence for $\mathrm{Na}^{+} / \mathrm{Ca}^{2+}$ exchange-dependent $\mathrm{Ca}_{i}^{2+}$ transient and contraction. The combination of pharmacological interventions substantially altered the pattern of the membrane potential, $\mathrm{Ca}_{\mathrm{i}}^{2+}$ transient, and isometric tension traces, as shown in Fig. 1 (top). The rapid, spike-like rise in $\mathrm{Ca}_{\mathrm{i}}^{2+}$ observed under control conditions (left panel) disappeared. Instead, after the stimulus, $\mathrm{Ca}_{\mathbf{i}}^{2+}$ slowly increased with an ascending

1. Abbreviations used in this paper: $\mathrm{DCB}$, dichlorobenzamil; $\mathrm{SR}$, sarcomplasmic reticulum; TTX, tetrodotoxin. convex pattern, which then abruptly began to descend with a downward convex pattern (right panel). The timing of the shift between the ascending and descending phases was coincidental with the initiation of membrane repolarization. The tension trace followed the $\mathrm{Ca}_{\mathrm{i}}^{2+}$ transient with a delay of $60-80 \mathrm{~ms}$. The effects of cumulative drug applications on these signals were shown in Fig. 1 (bottom). With $1 \times 10^{-5} \mathrm{M}$ DPI 201-106, the tension development was increased with its time course prolonged. The $\mathrm{Ca}_{\mathrm{i}}^{2+}$ transient showed a modest increase while maintaining its spikelike pattern (12). The action potential was also prolonged $(14,15)$. The addition of $1 \times 10^{-5} \mathrm{M}$ ryanodine significantly depressed the peak levels of tension and $\mathrm{Ca}_{i}^{2+}$. In addition, it delayed their time course. The $\mathrm{Ca}_{i}^{2+}$ transient lost its spike-like pattern $(20,21)$, and the tension and membrane potential showed marked prolongations. With 3 $\times 10^{-6} \mathrm{M}$ verapamil, the tension and $\mathrm{Ca}_{\mathrm{i}}^{2+}$ transient were further depressed $(12,22)$. In five of eight preparations, $\mathrm{Ca}_{\mathrm{i}}{ }^{2+}$ transients were no longer detected during depolarization. An additional increase in the verapamil concentration to $1 \times 10^{-5}$ $\mathrm{M}$ did not affect these signals $(n=2[17])$. Subsequently, however, by addition of $1 \times 10^{-5} \mathrm{M}$ acetylstrophanthidin and 4 $\mathrm{mM} \mathrm{Ca}{ }_{0}^{2+}$, the slow biphasic $\mathrm{Ca}_{i}^{2+}$ transient reappeared, and was associated with increased tension development. The time courses of membrane potential and tension were unchanged when compared to those with ryanodine and verapamil. The final pattern of signals produced by these cumulative drug additions was stable for over $20 \mathrm{~min}$, unless the level of $\mathrm{Ca}_{0}^{2+}$ was increased to higher concentrations $(>8 \mathrm{mM})$. In this case, relaxation of tension became progressively delayed.

To characterize the $\mathrm{Ca}_{\mathrm{i}}^{2+}$ transient and the corresponding action potential and tension trace, the preparation was challenged with changes in $\mathrm{Ca}_{0}^{2+}$, extracellular $\mathrm{Na}^{+}$concentration $\left(\mathrm{Na}_{\mathrm{o}}^{+}\right)$, supplementation with TTX, $\mathrm{Ni}^{2+}(17,23)$, or DCB $(24,25)$. In Fig. 2 (left), an increase in $\mathrm{Ca}_{\mathrm{o}}^{2+}$ from 4 to $8 \mathrm{mM}$ augmented the amplitude of the $\mathrm{Ca}_{\mathrm{i}}^{2+}$ transient, while the action potential did not significantly change (top row). In contrast, TTX at a concentration of $1 \times 10^{-6} \mathrm{M}$ (17) decreased the amplitude of the $\mathrm{Ca}_{i}^{2+}$ transient, which was accompanied by an abbreviated time course ( bottom, left). This condition was also associated with a shorter duration of the action potential, and the timing of repolarization was coincidental with the end of the ascending phase of $\mathrm{Ca}_{i}^{2+}$ as observed in Fig. 1. The effects of $\mathrm{Ca}_{0}^{2+}$ or TTX reached the steady-state within $3 \mathrm{~min}$. The data were consistent among seven preparations and suggested that the $\mathrm{Ca}_{\mathrm{i}}^{2+}$ transient depends on $\mathrm{Ca}_{\mathrm{o}}^{2+}$, and the shape of action potential. Of note, TTX, which blocks the DPI 201-106-activated $\mathrm{Na}^{+}$influx $(12,15)$, not only shortened the $\mathrm{Ca}_{\mathrm{i}}^{2+}$ transient, but also decreased its amplitude during membrane depolarization. This indicated that the $\mathrm{Ca}_{\mathrm{i}}^{2+}$ transient also depends on the level of intracellular $\mathrm{Na}^{+}\left(\mathrm{Na}_{i}^{+}\right)$even under the condition that the SR function was pharmacologically deleted (26). $\mathrm{Ni}^{2+}(5 \mathrm{mM})$, which is a divalent cation that blocks the $\mathrm{Na}^{+}$/ $\mathrm{Ca}^{2+}$ exchanger $(17,23)$, inhibited the remaining part of the $\mathrm{Ca}_{\mathrm{i}}^{2+}$ transient in the presence of $1 \times 10^{-6} \mathrm{M}$ TTX (bottom, right $)$. The suppression of the entire time course of $\mathrm{Ca}_{\mathrm{i}}^{2+}$ transients $(\sim 1 \mathrm{~s})$ by $\mathrm{Ni}^{2+}$ could not be attributed solely to its effect on the $\mathrm{T}$-type $\mathrm{Ca}^{2+}$ channel because duration of this channel activation is at most $100 \mathrm{~ms}$ in various ventricular cells (2730 ). In Fig. 2 (right), the $\mathrm{Na}^{+}$concentration of the solution was reduced by replacing $100 \mathrm{mM} \mathrm{NaCl}$ with the equimolar $\mathrm{LiCl}$ (Sigma Chemical Co.) With $\mathrm{Li}^{+}$, the $\mathrm{Ca}_{\mathrm{i}}^{2+}$ transients were rapidly depressed to below the minimally detectable level in 


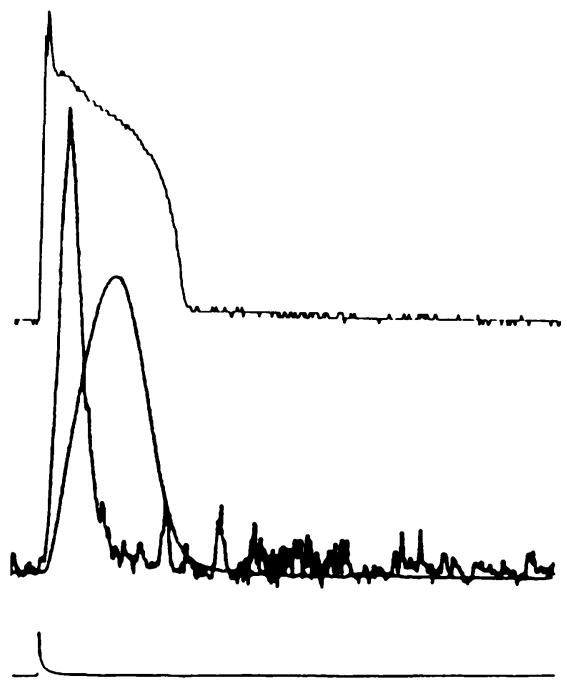

$\sqrt{400 \mathrm{~ms}}$

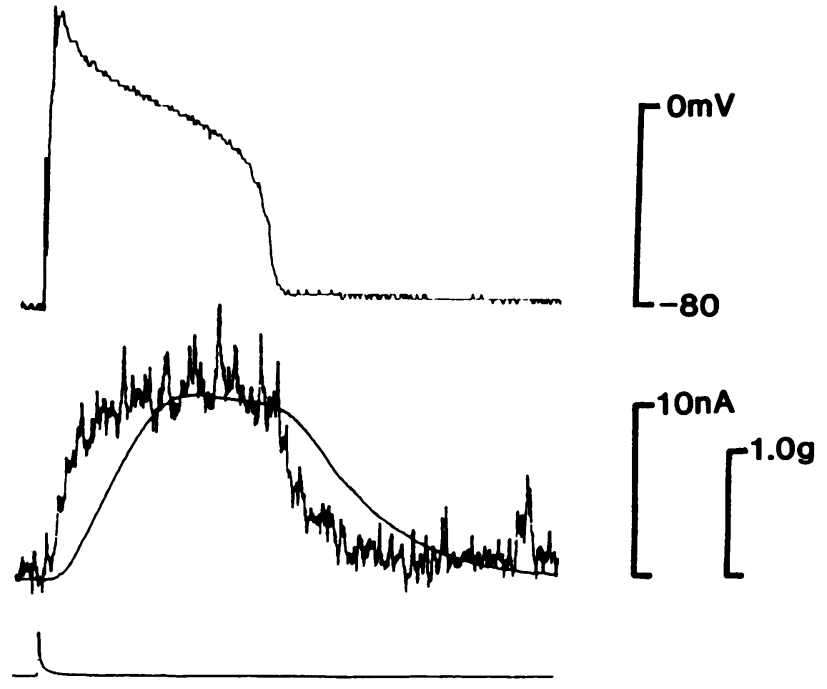

$400 \mathrm{~ms}$

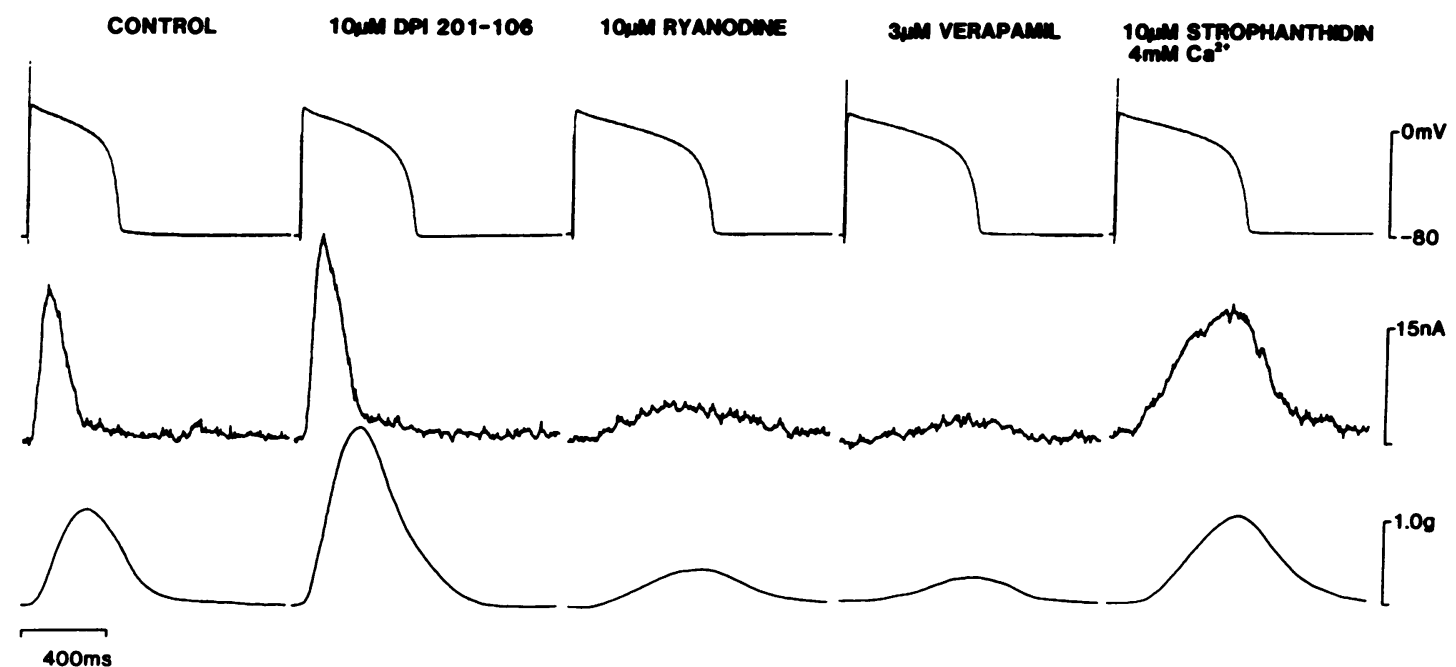

Figure 1. Top panel: Simultaneous recordings of action potential (top), $\mathrm{Ca}_{\mathrm{i}}^{2+}$ transient (notched signal, middle), tension trace (smooth signal,

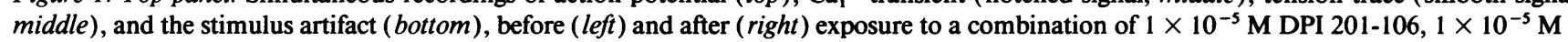
ryanodine, $3 \times 10^{-6} \mathrm{M}$ verapamil, $1 \times 10^{-5} \mathrm{M}$ acetylstrophanthidin, and $4 \mathrm{mM} \mathrm{Ca}^{2+}$. The $\mathrm{Ca}_{\mathrm{i}}^{2+}$ signals were averaged for 16 cycles. The calibration bar ( $10 \mathrm{nA})$ corresponds to $0.82 \mu \mathrm{M}$ of $\mathrm{Ca}^{2+}$ on the left and to $0.84 \mu \mathrm{M}$ on the right, respectively. $1 \mathrm{mM} \mathrm{Ca}_{0}^{2+}$ in the control (right); $30^{\circ} \mathrm{C}, 0.2 \mathrm{~Hz}$. Bottom panel: Modulations of the signals during each step of the cumulative drug additions. Drugs were added in the order from

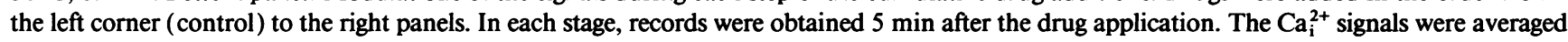
for eight cycles.

our system; therefore, the $\mathrm{Ca}_{i}^{2+}$ transients were also affected by the level of $\mathrm{Na}_{\mathrm{o}}^{+}$in a manner that $\mathrm{Li}^{+}$could not replace the role of $\mathrm{Na}_{\mathrm{o}}^{+}(9)$. We further tested the effects of DCB, an amiloride derivative known to block the $\mathrm{Na}^{+} / \mathrm{Ca}^{2+}$ exchange site relatively selectively $(24,25)$. After verifying in vitro that DCB does not affect aequorin luminescence, we found that DCB ( 5 $\mathrm{mM}$ ) also blocked the $\mathrm{Ca}_{\mathrm{i}}^{2+}$ transient in a similar manner as observed during the $\mathrm{Ni}^{2+}$ protocol (data not shown). Taken together, results from all these pharmacological interventions on this preparation supported the hypothesis that the observed $\mathrm{Ca}_{\mathrm{i}}^{2+}$ transient and contraction were primarily mediated by the transsarcolemmal $\mathrm{Ca}^{2+}$ influx through $\mathrm{Na}^{+} / \mathrm{Ca}^{2+}$ exchange during membrane depolarization.
Alteration of $\mathrm{Ca}_{i}^{2+}$, tension, and action potential during hypoxia and reoxygenation. The muscle was subjected to acute hypoxia for $20 \mathrm{~min}$, and then returned to control conditions for reoxygenation. The composition of the superfusate other than the gaseous mixtures was unchanged. During the initial half of the hypoxic period, the $\mathrm{Ca}_{\mathrm{i}}^{2+}$ transient, action potentials, and tension traces did not change detectably. However, during the second half of the hypoxic period, the action potential gradually shortened, which was accompanied by an abbreviation of the $\mathrm{Ca}_{\mathrm{i}}^{2+}$ transient and a decrease in peak tension development (19). The resting levels of $\mathrm{Ca}_{\mathrm{i}}^{2+}$ and tension started to increase during the last quarter of the hypoxic period (Fig. 3). The changes in these measurements at the end of a 20-min hypoxic 


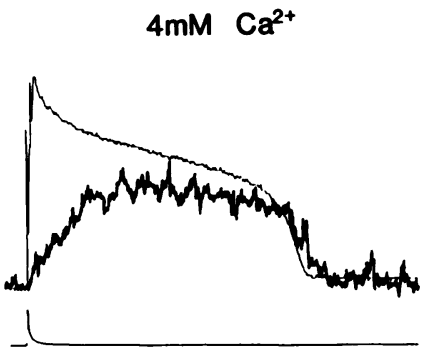

$8 m M \mathrm{Ca}^{2+}, 1 \mu \mathrm{M}$ TTX

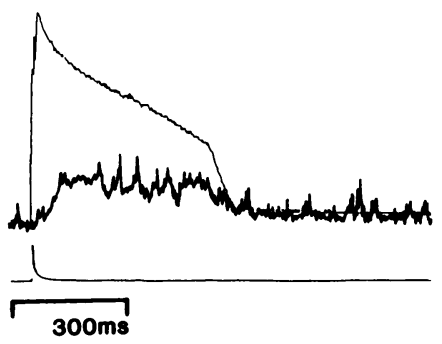

$8 \mathrm{mM} \mathrm{Ca}{ }^{2+}$
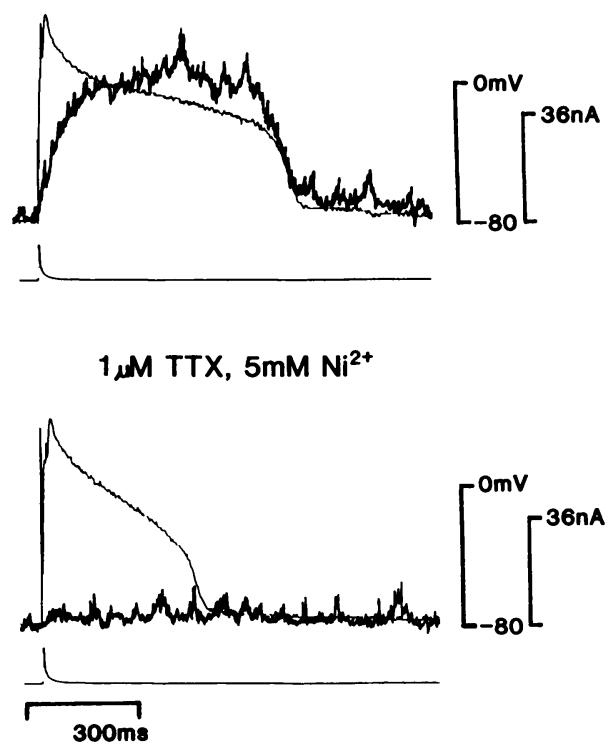

Low $\mathrm{Na}^{+}$
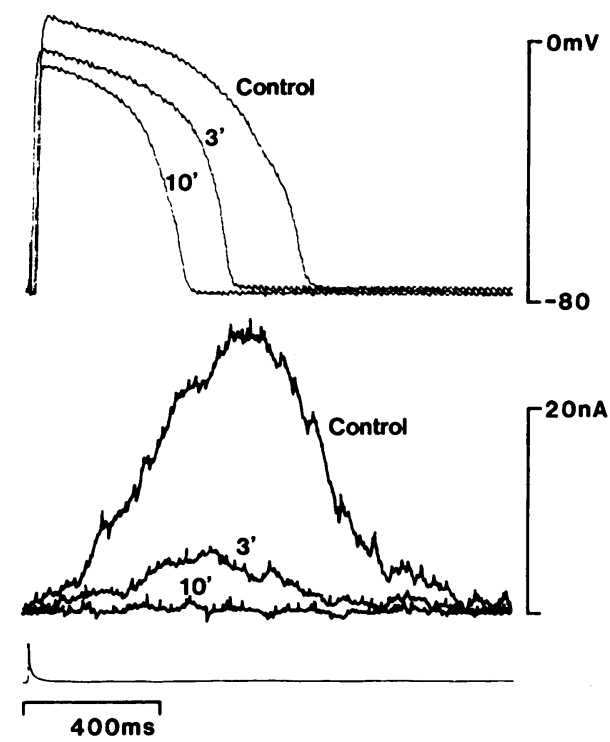

Figure 2. Left panel: In each panel, simultaneous records of action potential, $\mathrm{Ca}_{\mathrm{i}}^{2+}$ transient, and the stimulus artifact are shown in a muscle treated with a combination of DPI 201-106, ryanodine, and verapamil as described in Fig. 1 . The $\mathrm{Ca}^{2+}$ concentration of the solution was increased from $4 \mathrm{mM}($ top, left $)$ to $8 \mathrm{mM}($ top, right $)$. Then, $1 \mu \mathrm{M}$ TTX (bottom, left $)$ and $5 \mathrm{mM} \mathrm{Ni}{ }^{2+}($ bottom, right $)$ were cumulatively added to the solution. Data were obtained from the same muscle. The $\mathrm{Ca}_{\mathrm{i}}^{2+}$ signals were averaged for 32 cycles. The calibration bar ( $36 \mathrm{nA}$ ) corresponds to $0.60 \mu \mathrm{M}$ of $\mathrm{Ca}^{2+}$ in all panels. $30^{\circ} \mathrm{C}, 0.2 \mathrm{~Hz}$. Right panel: Effects of lowering $\mathrm{Na}_{\mathrm{o}}^{+}$by $100 \mathrm{mM} \mathrm{Li}^{+}$substitution on action potentials (top) and the $\mathrm{Ca}_{\mathrm{i}}^{2+}$ transients (middle) are shown. Signals were obtained during the process $\left(3 \mathrm{~min} ; 3^{\prime}\right)$ and at the steady state $\left(10 \mathrm{~min} ; 10^{\prime}\right)$ after the $\mathrm{Li}^{+}$substitution. The $\mathrm{Ca}_{\mathrm{i}}^{2+}$ transients were averaged for 16 cycles. The calibration bar $(20 \mathrm{nA})$ corresponds to $0.52 \mu \mathrm{M}$ of $\mathrm{Ca}^{2+} .30^{\circ} \mathrm{C}, 0.2 \mathrm{~Hz}$.

period are summarized in Table I. During reoxygenation, the data acquisition was interrupted for 1 min during switching the superfusates. When the measurements were re-started, we consistently observed that the $\mathrm{Ca}_{\mathrm{i}}^{2+}$ signals increased in peak amplitude and exceeded the control level before hypoxia (Fig. 3). Thus, there was a substantial increase in the peak $\mathrm{Ca}_{i}^{2+}$ after reoxygenation. Despite this increase in $\mathrm{Ca}_{\mathrm{i}}^{2+}$, the biphasic pattern of the $\mathrm{Ca}_{i}^{2+}$ signals was unchanged. That is, they consisted of ascending convex and descending concave curves and, although the time course was abbreviated by the shorter action potential, the peak was associated with the timing of repolarization. Data from $3 \mathrm{~min}$ after reoxygenation are summarized in Table I. The shortened action potential duration was again prolonged, but did not recover to the control value. The depressed tension trace did not show a corresponding increase or recovery in response to the increased $\mathrm{Ca}_{i}^{2+}$ level, which is consistent with previous reports in the reperfused or reoxygenated myocardium $(19,21,31,32)$. The increase in $\mathrm{Ca}_{\mathrm{i}}^{2+}$ gradually declined, but remained elevated at $5 \mathrm{~min}$ of reoxygenation when the measurement was terminated for the Triton X-100 perfusion. In order to further test the hypothesis that this increase in $\mathrm{Ca}_{i}^{2+}$ with reoxygenation was mediated by mechanisms other than $\mathrm{Na}^{+} / \mathrm{Ca}^{2+}$ exchange (such as nonspecific $\mathrm{Ca}^{2+}$ leak, $\mathrm{Ca}^{2+}$ pump inhibition, or release of $\mathrm{Ca}^{2+}$ from the internal buffers), the hypoxia/reoxygenation protocol was repeated in the presence of $5 \mathrm{mM} \mathrm{Ni}^{2+}(n=3)$. When $\mathrm{Ni}^{2+}$ was added to the preparation $10 \mathrm{~min}$ before hypoxia, the $\mathrm{Ca}_{\mathrm{i}}^{2+}$ signals became flat at the base line, as shown in Fig. 2 and there was no detectable transient or rise throughout the hypoxia/ reoxygenation period (data not shown). This means that the increase in $\mathrm{Ca}_{\mathrm{i}}^{2+}$ at the point of reoxygenation was facilitated (during hypoxia) and/or mediated (at reoxygenation) by $\mathrm{Ni}^{2+}$-sensitive mechanisms.

\section{Discussion}

Results from an increasing number of studies have suggested a role for $\mathrm{Na}^{+} / \mathrm{Ca}^{2+}$ exchange in producing $\mathrm{Ca}_{i}^{2+}$ overload during reoxygenation $(8,9,11,33-35)$. However, the present study provides the first direct evidence of $\mathrm{Ca}_{i}^{2+}$ loading by the exchanger into a reoxygenated working myocardial preparation that is actively contracting and relaxing. This study also demonstrated that $(a)$ a putative increase in the cytosolic $\mathrm{Ca}^{2+}$ level by sarcolemmal $\mathrm{Ca}^{2+}$ influx occurs immediately after a period of hypoxia in mammalian ventricular myocardium and (b) because the SR function and the sarcolemmal $\mathrm{Ca}^{2+}$ channels are pharmacologically blocked in this preparation, these subcellular functions are not necessary for $\mathrm{Ca}_{i}^{2+}$ loading during reoxygenation. Furthermore, the results suggest that $\mathrm{Na}_{i}^{+}$loading during the hypoxic period is the driving force behind excessive $\mathrm{Ca}^{2+}$ influx via $\mathrm{Na}^{+} / \mathrm{Ca}^{2+}$ exchange during this period, which will be discussed later.

In the presence of ryanodine and verapamil $(16,17,36)$, the $\mathrm{Ca}_{\mathrm{i}}^{2+}$ transients we observed were dependent on $\mathrm{Ca}_{0}^{2+}$, and on the membrane potential. The $\mathrm{Ca}_{\mathrm{i}}^{2+}$ transients were enhanced by interventions that increased $\mathrm{Na}_{i}^{+}$activity, and were blocked by lowering $\mathrm{Na}_{\mathrm{o}}^{+}, \mathrm{TTX}, \mathrm{Ni}^{2+}$, and DCB. These observations are consistent with the notion that the primary determinant of the $\mathrm{Ca}_{i}^{2+}$ transient in these experiments is $\mathrm{Na}^{+} / \mathrm{Ca}^{2+}$ exchange. We further tested whether the $\mathrm{SR} \mathrm{Ca}^{2+}$ handling was sufficiently inhibited in our preparations by using a short-term force-interval response ( $n=2$ [37]). By varying the coupling interval of the extra stimuli from 2 to $5 \mathrm{~s}$, we found no alteration of the levels of $\mathrm{Ca}_{\mathrm{i}}^{2+}$ nor tension of the postextrastimulation beats (37). This was also true even when a train of conditioning stimuli (three beats with a 2-s interval) was applied to the muscle (data not shown). Therefore, the $\mathrm{Ca}_{i}^{2+}$ transients 

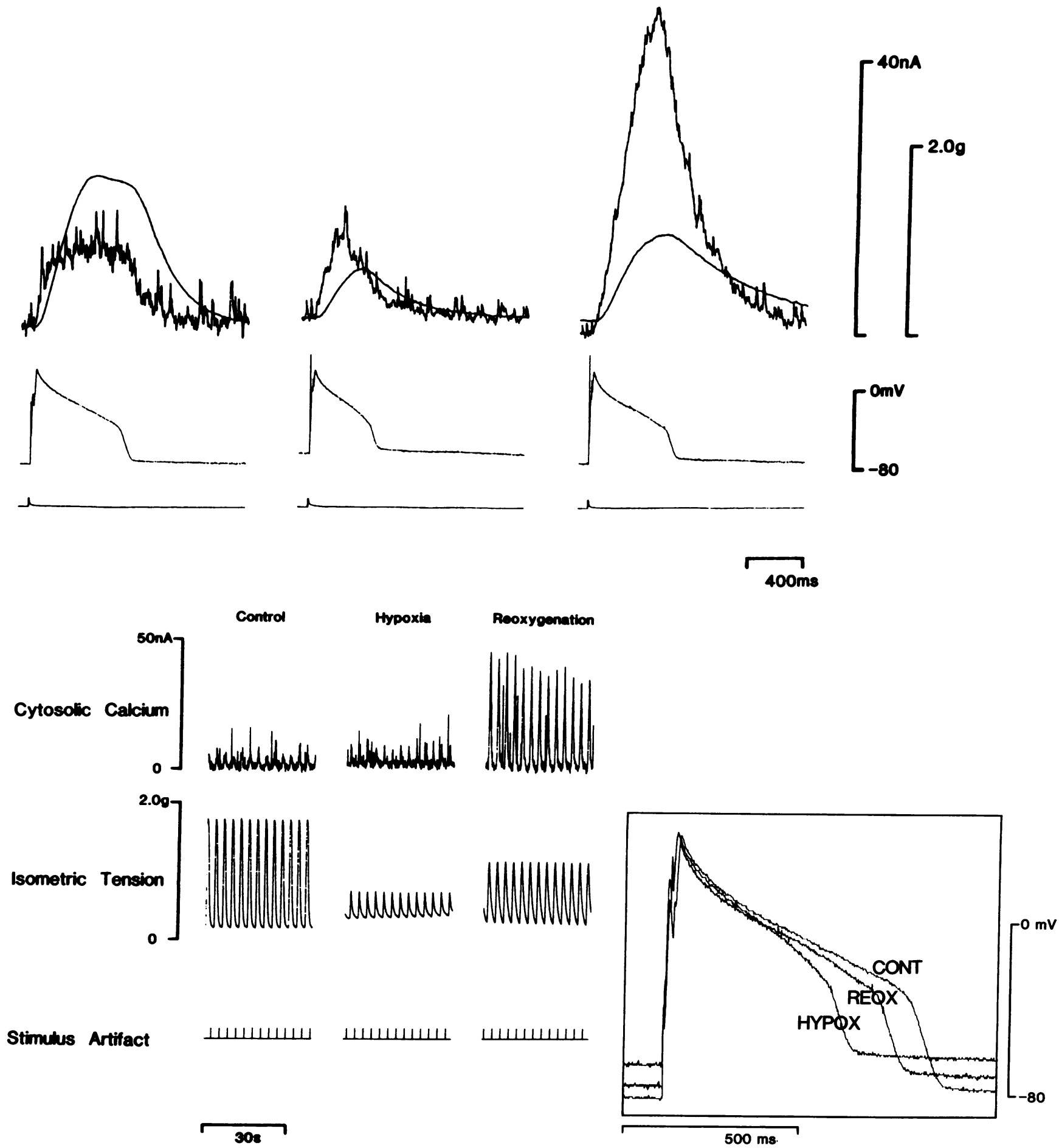

Figure 3. Top panel: Simultaneous records of the $\mathrm{Ca}_{\mathbf{i}}^{2+}$ transient, tension trace (top), action potential (middle), and the stimulus artifact (bottom), during control conditions (left), during 20-min hypoxia (middle), and during 3-min reoxygenation (right). Data were serially obtained from the same muscle. The $\mathrm{Ca}_{\mathrm{i}}^{2+}$ signals were averaged for 16 cycles. The calibration bar $(40 \mathrm{nA})$ corresponds to $1.10 \mu \mathrm{M}$ of $\mathrm{Ca}{ }^{2+}$ in control, $1.14 \mu \mathrm{M}$ in hypoxia, and $1.20 \mu \mathrm{M}$ in reoxygenation, respectively. $30^{\circ} \mathrm{C}, 0.33 \mathrm{~Hz}$. Bottom left panel: The slow tracings of Ca ${ }_{i}^{2+}$ transients, tension, and the stimulus artifacts in these conditions are shown. Bottom right panel: Action potentials are superimposed for comparison. CONT, control; HYPOX, hypoxia; REOX, reoxygenation.

we observed did not contain an interval-dependent component, which is attributable to released $\mathrm{Ca}^{2+}$ from the SR (37, 38 ). During the low $\mathrm{Na}_{0}^{+}$protocol (replaced with $\mathrm{Li}^{+}$), the $\mathrm{Ca}_{\mathrm{i}}^{2+}$ transient was markedly depressed with relaxed tension.
Since $\mathrm{Li}^{+}$blocks the forward mode as well as the reverse mode of the exchanger, this observation also suggested that the cytosolic $\mathrm{Ca}^{2+}$ supplied through the $\mathrm{SR}$ or the sarcolemmal $\mathrm{Ca}^{2+}$ channels were sufficiently blocked so that the remaining $\mathrm{Ca}^{2+}$ 
Table I. Effects of Hypoxia and Reoxygenation on the Amplitude and Time Course of Light and Tension Responses and Electrophysiologic Properties of Ferret Papillary Muscles

\begin{tabular}{|c|c|c|c|}
\hline & Control & Hypoxia & Reoxygenation \\
\hline Developed tension $\left(\mathrm{g} / \mathrm{mm}^{2}\right)$ & $2.6 \pm 0.7$ & $0.5 \pm 0.4^{\ddagger}$ & $1.2 \pm 0.6^{* \| 1}$ \\
\hline $\begin{array}{l}\text { Time to the end of tension } \\
\text { ascent }(m s)\end{array}$ & $880 \pm 192$ & $454 \pm 170^{*}$ & $823 \pm 250^{\S}$ \\
\hline $\begin{array}{l}\text { Time to } 80 \% \text { tension } \\
\text { regression }(\mathrm{ms})\end{array}$ & $392 \pm 84$ & $256 \pm 102$ & $681 \pm 334^{\ddagger 11}$ \\
\hline Peak $\mathrm{Ca}_{i}^{2+}(\mu M)$ & $0.8 \pm 0.3$ & $0.5 \pm 0.2^{*}$ & $1.2 \pm 0.5^{* \|}$ \\
\hline Resting $\mathrm{Ca}_{\mathrm{i}}^{2+}(\mu M)$ & 0.2 & 0.3 & 0.4 \\
\hline $\begin{array}{l}\text { Time to the end of } \mathrm{Ca}_{\mathrm{i}}^{2+} \\
\text { ascent }(m s)\end{array}$ & $805 \pm 150$ & $380 \pm 172^{*}$ & $711 \pm 286^{\S}$ \\
\hline $\begin{array}{l}\text { Time to } 80 \% \mathrm{Ca}_{\mathrm{i}}^{2+} \\
\text { regression }(\mathrm{ms})\end{array}$ & $110 \pm 22$ & $106 \pm 34$ & $143 \pm 66$ \\
\hline $\mathrm{APD}_{80}(m s)$ & $866 \pm 131$ & $404 \pm 153^{\ddagger}$ & $720 \pm 232^{\S}$ \\
\hline $\begin{array}{l}\text { Resting membrane potential } \\
(\mathrm{m} V)\end{array}$ & $-76 \pm 6$ & $-56 \pm 10^{*}$ & $-70 \pm 10$ \\
\hline
\end{tabular}

Data are mean $\pm \operatorname{SD}(n=7)$. Because of relative insensitivityof aequorin to the lower level of $\mathrm{Ca}^{2+}$ and the basal noise from the photomultiplier tube, quantitative estimation of resting $\mathrm{Ca}_{i}^{2+}$ was performed in two muscles during control, four muscles during hypoxia, and five muscles during reoxygenation, in which detectable rises of the signal level were observed. The mean values of this measurement are presented. $\mathrm{APD}_{80}$, action potential duration to the $80 \%$ regression; ${ }^{* \ddagger} P$ $<0.05$ and $P<0.01$ to the control values; $\$$ " $P<0.05$ and $P<0.01$ to the hypoxia values, respectively.

leaks were able to be handled by the sarcolemmal Ca pump $(39,40)$.

We did not directly measure the $\mathrm{Na}^{+} / \mathrm{Ca}^{2+}$ exchange current $\left(I_{\mathrm{NaCa}}\right)$ in our multicellular preparation; however, the results suggested that $I_{\mathrm{NaCa}}$ might operate in the reverse mode during the ascending phase of the $\mathrm{Ca}_{i}^{2+}$ transient (hence, during membrane depolarization ) and it might switch to the forward mode at the initiation of the membrane repolarization. Such a sustantation of the reverse mode of $I_{\mathrm{NaCa}}$ throughout depolarization may not be consistent with reported patterns of $I_{\mathrm{NaCa}}$ in the working myocardium, where $I_{\mathrm{NaCa}}$ was estimated to be predominantly directed inwards, except for the very early phase of the action potential $(41,42)$. Therefore, we tried to estimate the instantaneous direction and relative scales of $I_{\mathrm{NaCa}}$ at every 10 -ms interval in our preparation using a thermodynamic equation initially proposed by DiFrancesco and Noble $(16,17,24,43)$, which is given as follows:

$$
\begin{aligned}
I_{\mathrm{NaCa}}= & k_{\mathrm{NaCa}}\left[\exp (r E F / R T)\left[\mathrm{Ca}_{\mathrm{o}}^{2+}\right]\left[\mathrm{Na}_{\mathrm{i}}^{+}\right]^{3}\right. \\
& \left.-\exp (-(1-r) E F / R T)\left[\mathrm{Ca}_{\mathrm{i}}^{2+}\right]\left[\mathrm{Na}_{\mathrm{o}}^{+}\right]^{3}\right],
\end{aligned}
$$

where $k_{\mathrm{NaCa}}$ is a scaling factor which includes the rate constant of exchanger translocation at $E_{\mathrm{m}}=0 ; r$ is the fractional distance through the membrane of the limiting energy barrier. A value of 0.35 was used in accordance with previous studies with guinea-pig myocytes $(17,23,24) ; E$ is the membrane potential; $R, T$, and $F$ have the usual thermodynamic meanings. The activity coefficients of $\mathrm{Na}_{\mathrm{o}}^{+}$and $\mathrm{Na}_{\mathrm{i}}^{+}$were assumed to be 0.7 (44). See footnote 2 for more assumptions and discussion. As shown in Fig. 4, we found that under our experimental conditions, the $\mathrm{Na}^{+} / \mathrm{Ca}^{2+}$ exchange current might be outwardly directed during depolarization. This implies that the exchanger acts in the reverse mode for $\mathrm{Ca}^{2+}$ loading during this period. With repolarization, the current abruptly shifted to the inward direction; the forward mode of the exchanger acting to exclude $\mathrm{Ca}^{2+}$ from the cytoplasm. The dip in the current immediately after repolarization appears to be consistent with the transient inward currents that have been reported in systems using voltage-clamped single myocytes $(17,45,46)$, although the shape was somewhat smoothed by gradual membrane repolarization under our conditions (e.g., compare with Fig. 2 in Beuckelmann and Wier [17]). Although the $\mathrm{Na}_{i}^{+}$level in the range of 12 to $18 \mathrm{mM}$ is higher than the reported value in ferret ventricular myocardium $(18,44)$, this appears to be within the expected range under our experimental conditions using acetylstrophanthidin and DPI 201-106 (18,47). As suggested by Leblanc and Hume (26), the $\mathrm{Na}_{\mathrm{i}}^{+}$value around the exchanger could be much higher, especially during the early phase of depolarization: however, this possibility does not affect our conclusion obtained from this estimation that the exchanger operates in reverse mode during this period.

Besides $\mathrm{Na}^{+} / \mathrm{Ca}^{2+}$ exchange, the $\mathrm{Ca}_{i}^{2+}$ transient might be modulated by other $\mathrm{Ca}_{\mathrm{i}}^{2+}$-related subcellular functional units. Those include the sarcolemmal $\mathrm{Ca}^{2+}$ pump (48), sarcolemmal $\mathrm{Ca}^{2+}$ leak currents $(17)$ and internal $\mathrm{Ca}^{2+}$ buffers $(49,50)$. Especially, during hypoxia and reoxygenation, these subcellular functions may be altered, and, could cause $\mathrm{a} \mathrm{Ca}_{i}^{2+}$ rise with

2. To estimate $I_{\mathrm{NaCa}}$ in the working muscle, we made the following assumptions: (a) $\mathrm{Na}^{+}$versus $\mathrm{Ca}^{2+}$ exchange is carried with $3: 1$ stoichiometry in ferret myocardium as shown in other species $(17,23,45$, $55) ;(b)$ none of the effects of changes in $\mathrm{Ca}_{\mathrm{i}}^{2+}$ or membrane potential on the mode and activity of the exchanger are delayed over the order of milliseconds $(40,42) ;(c) \mathrm{Na}_{i}^{+}$at the internal site of the exchanger is kept constant during a cardiac cycle $(17,38) ;(d)$ the instantaneous $\mathrm{Ca}_{\mathrm{i}}^{2+}$ as measured by aequorin represents the average level through the cytosolic space (63), which might not significantly differ from the level at the exchangers' translocation site inside the sarcolemma $(17,20)$. Except for the very early phase of depolarization when the action potential did still not reach the plateau, change in the level of $\mathrm{Ca}_{i}^{2+}$ was very slow and smooth (as shown in Fig. 5, the time constant of the descending phase was around $1 \mathrm{~s}$, which is consistent with a recent report [39]). Homogeneous (no oscillatory) distributions of $\mathrm{Ca}_{i}^{2+}$ through the cytosolic space (64) and their gradual change during depolarization under similar pharmacological interventions were also shown in several studies using the isolated single myocyte $(20,65)$. Accordingly, during each 10-ms interval, we assumed the level of $\mathrm{Ca}_{i}^{2+}$ to be constant; hence, the rapidly-accessible $\mathrm{Ca}^{2+}$ buffers, such as troponin, calmodulin, or phosphocreatine $(17,37)$, are equilibrated. Then, the current during that period was estimated for a given set of $\mathrm{Ca}_{i}^{2+}, \mathrm{Na}_{i}^{+}$, and the membrane voltage. It should be noted that such estimations could include substantial errors in a manner dependent on the rate of $\mathrm{Ca}_{i}^{2+}$ change, and should not be applied to the control condition such as the left panel of Fig. 1, in which $\mathrm{Ca}_{i}^{2+}$ transients and their buffers underwent more dynamic changes. In addition, our assumption of the constancy of the $\mathrm{Na}_{i}^{+}$level during a cardiac cycle may not be consistent with a recent theory that $\mathrm{Na}^{+} / \mathrm{Ca}^{2+}$ exchange may predominantly access a discrete cation pool around the inner sarcolemma, in which the $\mathrm{Na}_{i}^{+}$level could be transiently increased by $\mathrm{Na}^{+}$influx from the fast $\mathrm{Na}^{+}$channels $(26,38,66)$. However, at least under the conditions in which the $\mathrm{Ca}^{2+}$ influxes via the SR and sarcolemmal $\mathrm{Ca}^{2+}$ channels were blocked, $I_{\mathrm{NaCa}}$ was reported to be directly correlated with the level of space-averaged $\mathrm{Ca}_{\mathrm{i}}^{2+}$ and the membrane potential, but not with $\mathrm{Na}_{\mathrm{i}}^{+}(16,17)$. In the same experimental conditions, $\mathrm{Ca}_{i}^{2+}$ and $\mathrm{I}_{\mathrm{NaCa}}$ measurements with (17) or without (16) $\mathrm{Na}^{+}$channel blockade showed undetectable changes. Moreover, in the presence of caffeine, Bridge et al. clearly showed that the $\mathrm{Na}^{+} / \mathrm{Ca}^{2+}$ exchanger keeps free access to the entire pool of cytoplasmic $\mathrm{Ca}^{2+}(40,48)$. 

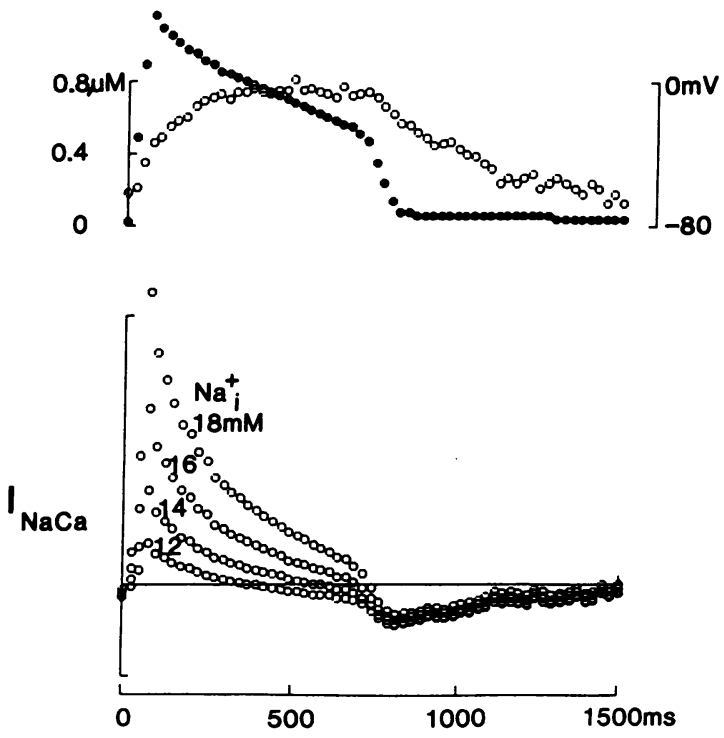

Figure 4. The calibrated $\mathrm{Ca}_{\mathrm{i}}^{2+}$ transient (o) and the corresponding action potential $(\bullet)$ are shown in the top row. Data were sampled at 10-ms intervals. By adapting these data to the DiFrancesco and Noble equation, relative magnitudes and time courses of the transsarcolemmal current via $\mathrm{Na}^{+} / \mathrm{Ca}^{2+}$ exchange were estimated $\left(I_{\mathrm{NaCa}} ;\right.$ bottom row). $\mathrm{Na}_{i}^{+}$level was assumed to be 12-18 mM. An original trace of this figure is presented in the left panel of Figure 3 (top). For details, see the discussion and footnote 2 .

reoxygenation. The following discussions, however, do not support any role for these functions on the observed pattern of $\mathrm{Ca}_{\mathrm{i}}^{2+}$ during reoxygenation. Even after the blockade of SR function, most of the $\mathrm{Ca}^{2+}$ that entered the intracellular space would be captured by the buffering systems, which include the internal sarcolemmal surface, calmodulin, troponin, and phosphocreatine. If the buffer capacity were suddenly reduced at reoxygenation, the $\mathrm{Ca}^{2+}$ released from the binding sites might cause an increase in $\mathrm{Ca}_{i}^{2+}$. In this case, the altered profile of $\mathrm{Ca}_{\mathrm{i}}^{2+}$ after reoxygenation would consist of a primary increase in the diastolic or resting level of $\mathrm{Ca}_{i}^{2+}$, since the released $\mathrm{Ca}^{2+}$ from the internal sites would remain in the cytosolic space until removed by the secondarily activated $\mathrm{Ca}^{2+}$ pump or the exchanger. $\mathrm{Ca}^{2+}$ influx during depolarization would instead be inhibited by the persistent rise of $\mathrm{Ca}_{i}^{2+}$. Such alterations in the $\mathrm{Ca}_{\mathrm{i}}^{2+}$ pattern by internal $\mathrm{Ca}^{2+}$ release have been observed with acidotic interventions $(51,52)$ or in studies of acute global ischemia in mammalian ventricular myocardium $(1,53)$. In these studies, the descending phases of the $\mathrm{Ca}_{i}^{2+}$ transients were delayed, which were also attributed to effects of the decreased buffer capability. These expected patterns of change in the $\mathrm{Ca}_{\mathrm{i}}^{2+}$ signal by the reduction of internal buffer capacity are however, inconsistent with our observations during reoxygenation. In our study, the $\mathrm{Ca}_{i}^{2+}$ transients were primarily augmented by an increase in the systolic amplitude, which was associated with a relatively small increase in basal $\mathrm{Ca}_{\mathrm{i}}^{2+}$ levels. This implies that the increase in $\mathrm{Ca}_{\mathbf{i}}^{2+}$ occurred during depolarization and the increase was dynamic rather than static. The bottom row of Fig. 5 shows a comparison of the descending slope of $\mathrm{Ca}_{i}^{2+}$ signals under three conditions, by adjusting their peak $\mathrm{Ca}_{i}^{2+}$ values to equivalent levels. The slope during reoxygenation was lower than that of the control, but was higher than the slope during hypoxia. This observation contrasted with the expected delay in the $\mathrm{Ca}_{\mathrm{i}}^{2+}$ descent, which should be apparent if a reduced buffer capacity plays the primary role in the $\mathrm{Ca}_{\mathrm{i}}^{2+}$ increase during reoxygenation. Instead, the descending slopes of $\mathrm{Ca}_{\mathrm{i}}^{2+}$ appear to be dependent on the resting membrane potential, which is the chief determinant of slope when the $\mathrm{Ca}_{\mathbf{i}}^{2+}$ levels are primarily regulated by $\mathrm{Na}^{+} / \mathrm{Ca}^{2+}$ exchange $(17,39,48,54)$.

The ohmic leak of $\mathrm{Ca}^{2+}$ may also increase at the time of reperfusion, which might shift the resting $\mathrm{Ca}_{i}^{2+}$ to higher levels. However, this increase does not appear to explain the observed dynamic increase in $\mathrm{Ca}_{i}^{2+}$, as discussed above.

Impaired $\mathrm{Ca}^{2+}$ pump activity possibly causes an increase in $\mathrm{Ca}_{\mathrm{i}}^{2+}$ after reoxygenation. This possibility also does not fit the observed $\mathrm{Ca}_{i}^{2+}$ pattern because $\mathrm{Ca}^{2+}$ pump inhibition should further delay the $\mathrm{Ca}_{i}^{2+}$ descent when it causes an increase in peak $\mathrm{Ca}_{i}^{2+}(48)$. Taken together, none of these subcellular functions appear to modulate the $\mathrm{Ca}_{\mathrm{i}}^{2+}$ transient towards the profile observed during reoxygenation. Besides, if these modulatory effects were activated by reoxygenation, they might increase the $\mathrm{Ca}_{\mathrm{i}}^{2+}$ levels even in the presence of $\mathrm{Ni}^{2+}$. However, this was not the case in our $\mathrm{Ni}^{2+}$ study.

Recent studies have revealed evidence consistent with the concept that the $\mathrm{Na}^{+} / \mathrm{Ca}^{2+}$ exchange carries ions via specific ion binding sites that operate in an asymmetrical manner between inside and outside the membrane $(23,55)$. The thermodynamic equation proposed by DiFrancesco and Noble (43) may still be adaptable to these series of chemical reactions because the $\mathrm{Na}^{+} / \mathrm{Ca}^{2+}$ exchange current is under dynamic control primarily by $\mathrm{Ca}_{\mathrm{i}}^{2+}$ (high affinity of the internal binding sites to $\mathrm{Ca}^{2+}$ ) and the membrane potential (electronegicity) $(16,17,23,24,55)$. From this equation, the changes in these two parameters that were shown during reoxygenation appear to favor $\mathrm{Ca}^{2+}$ extrusion by the exchanger, since both increases in $\mathrm{Ca}_{\mathrm{i}}^{2+}$ and in the level of negativity of the resting potential increase the second term of the equation (inward current, thus, for $\mathrm{Ca}^{2+}$ efflux) while decreasing the first term (outward current for $\mathrm{Ca}^{2+}$ influx ). Therefore, changes in $\mathrm{Ca}_{\mathrm{i}}^{2+}$ and membrane potentials are not the direct driving forces for $\mathrm{Ca}^{2+}$ loading during reoxygenation. Instead, they appear to activate the exchanger against the $\mathrm{Ca}_{i}^{2+}$ excess in order to maintain the intracellular environment. The calculated exchange current and the net $\mathrm{Ca}^{2+}$ influx would be smaller during reoxygenation than those in the control state before hypoxia, if other parameters in the equation remain unchanged (Fig. 6, top). However, there are several lines of evidence suggesting that $\mathrm{Na}_{\mathrm{i}}^{+}$, which is one of the parameters assumed to be a constant in the above discussion, might change during the course of ischemia/reper-
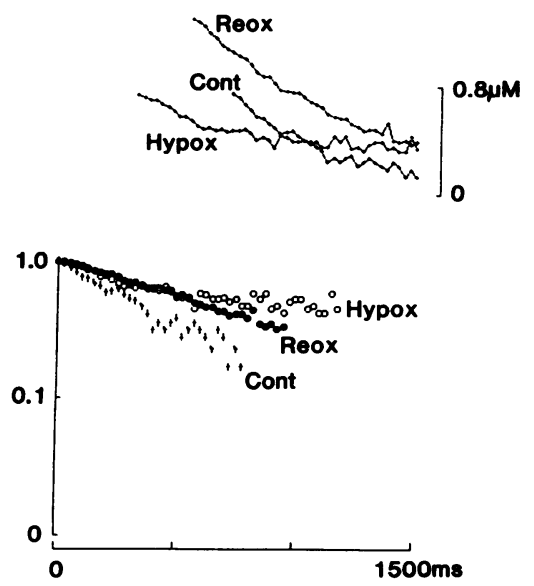

Figure 5. The descending phases of the $\mathrm{Ca}_{i}^{2+}$ transients shown in Fig. $3(t o p)$ were superimposed after the calibration process, as shown in the top row. The time courses of the $\mathrm{Ca}_{i}^{2+} \mathrm{de}-$ cline are presented in a semilogarithmic scale in the bottom row. The abbreviations are the same as in Fig. 3 (bottom right). 
fusion as well as during hypoxia/reoxygenation. Recent studies using NMR spectroscopy showed a three- to five-fold increase in $\mathrm{Na}_{\mathrm{i}}^{+}$at the end of 20-min global ischemia in Langendorff preparations $(33,56)$. In these studies, at the time of reperfusion, the $\mathrm{Na}_{i}^{+}$accumulation was abruptly shifted to a monoexponential decline towards the control level for over 10 min, demonstrating the reversal of the net $\mathrm{Na}_{i}^{+}$balance at the time of reperfusion. These observations not only provide supportive evidence for $\mathrm{Na}_{i}^{+}$excess during ischemia but also suggest a role of $\mathrm{Na}^{+} / \mathrm{Ca}^{2+}$ exchange during reperfusion, because the $\mathrm{Ca}_{\mathrm{i}}^{2+}$ accumulation and $\mathrm{Na}_{\mathrm{i}}^{+}$regression appear to be coincidental during this period. In studies of hypoxia, a time-dependent increase in $\mathrm{Na}_{\mathrm{i}}^{+}$was shown using ion-selective microelectrodes $(18,47)$. The level of increase was reported from $10 \mathrm{mM}$ in controls to $19 \mathrm{mM}$ during $25 \mathrm{~min}$ of hypoxia in the ferret ventricular muscle (18). If a similar level of $\mathrm{Na}_{i}^{+}$loading were assumed to occur at reoxygenation in our study, the net $\mathrm{Ca}^{2+}$ influx by the exchanger would be tremendously augmented even in the presence of a high $\mathrm{Ca}_{i}^{2+}$ and a low membrane potential (Fig. 6, bottom). This may not be surprising from the dynamic characteristics of $\mathrm{Na}^{+} / \mathrm{Ca}^{2+}$ exchange, since the increase in $\mathrm{Na}_{i}^{+}$affects the outward current by a factor of 3 , while changes in $\mathrm{Ca}_{\mathrm{i}}^{2+}$ modulate the inward current by a factor of 1 . Thus, when there was an equivalent increase in $\mathrm{Na}_{\mathrm{i}}^{+}$at the time of reoxygenation as demonstrated by other investigators, the observed increase in $\mathrm{Ca}_{i}^{2+}$ transient after reoxygenation could be attributed to the $\mathrm{Na}^{+} / \mathrm{Ca}^{2+}$ exchange process which operates according to its known characteristics.

There are a large number of factors that may modulate the exchanger activity (corresponding to $k_{\mathrm{NaCa}}$ in the equation [ 57 , 58]). Among them, redox agents increase the exchange rate up to 10-fold by promoting thiol-disulfate interchange in the protein (57). Because the production of reduced oxygen species might occur during reoxygenation (59-61), an abrupt activa-

\section{CONTROL}
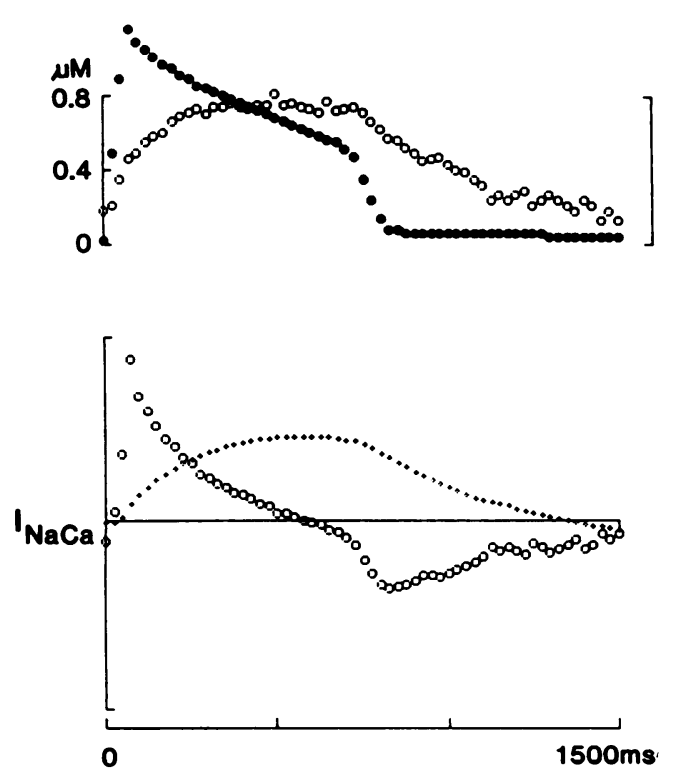

\section{$\mathrm{Na}^{+}$}

o

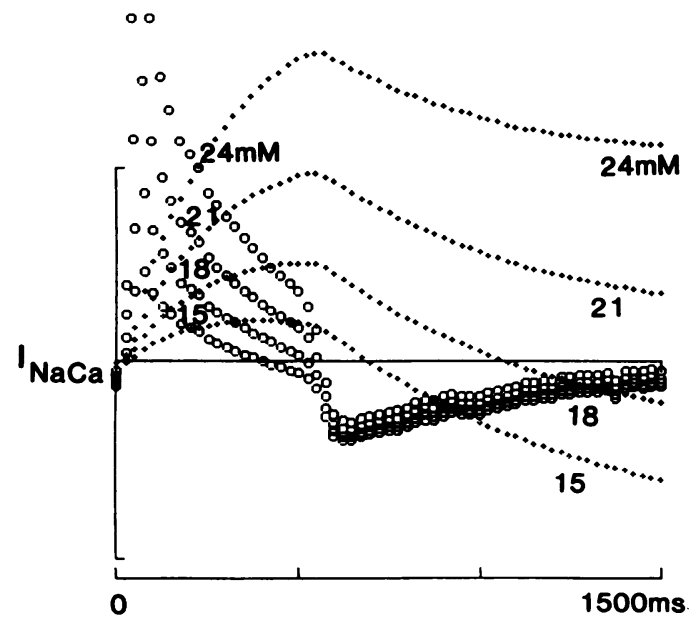

REOXYGENATION
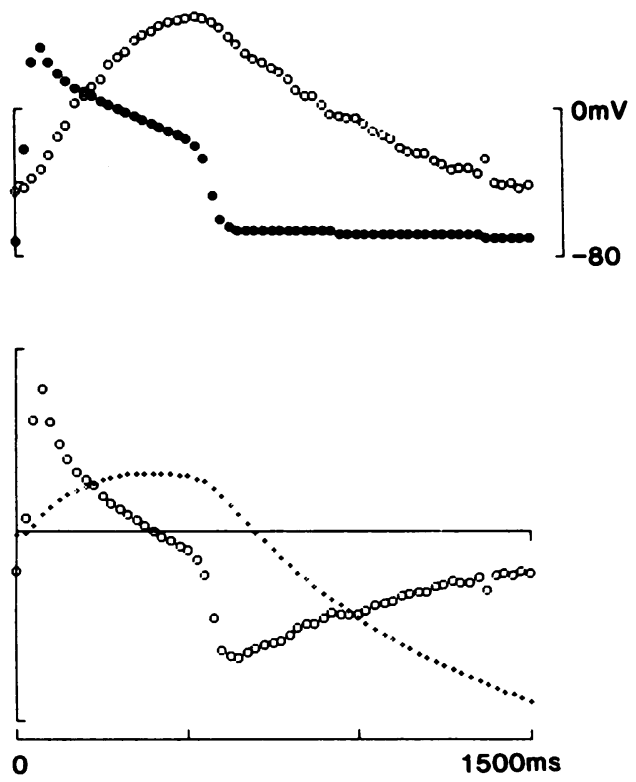

$\mathbf{K}_{\mathrm{NaCa}}$

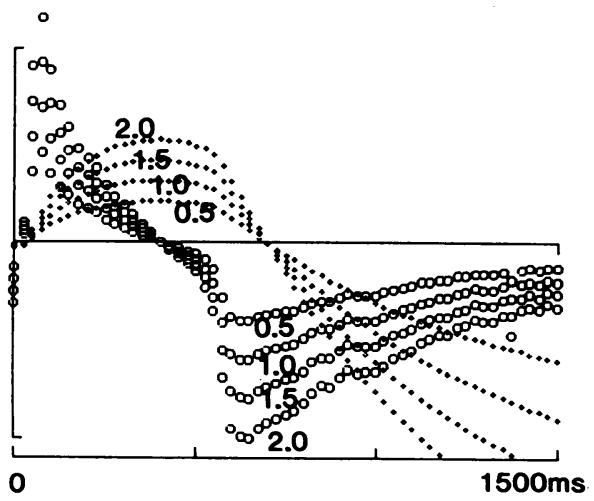

Figure 6. Top panel: The calibrated $\mathrm{Ca}_{i}^{2+}$ transient $(0)$ and the corresponding action potential $(\bullet)$ during control conditions (left) and during reoxygenation (right) are shown in the top row. In the bottom row, the transsarcolemmal current via $\mathrm{Na}^{+}$/ $\mathrm{Ca}^{2+}$ exchange (O) and the time integral (small dots) are estimated in the same manner as presented in Fig. 4. The level of $\mathrm{Na}_{i}^{+}$was assumed to be $15 \mathrm{mM}$ in both conditions. Note that the outward current $\left(\mathrm{Ca}^{2+}\right.$ influx ) is smaller during reoxygenation than during control unless their $\mathrm{Na}_{\mathrm{i}}^{+}$and $k_{\mathrm{NaCa}}$ are altered. Bottom panel: The transsarcolemmal current via $\mathrm{Na}^{+} / \mathrm{Ca}^{2+}$ exchange $(O)$ and the time integral $(\cdots \cdots)$ during reoxygenation were reassessed while the $\mathrm{Na}_{i}^{+}$values are varied from 15 to $24 \mathrm{mM}$ (left) or the $k_{\mathrm{NaCa}}$ values are modulated over the range of 0.5 to 2.0-times of the control (right). For the definition of the scaling factor, $k_{\mathrm{NaCa}}$, see the text. 
tion of $\mathrm{Na}^{+} / \mathrm{Ca}^{2+}$ exchange as detected by the sudden increase in the $\mathrm{Ca}^{2+}$ influx during this period may be due to modulatory effects by these free radicals (34). Of importance, the more rapid rate of the exchanger's translocation facilitates $\mathrm{Ca}^{2+} \mathrm{ef}-$ flux as well as $\mathrm{Ca}^{2+}$ influx, and the net effect might be determined by the combination of $\mathrm{Ca}_{i}^{2+}, \mathrm{Na}_{i}^{+}$, and the membrane potential (Fig. 6, bottom). Hence, under a normal transmembrane $\mathrm{Na}^{+}$gradient and resting potential, this activation may lead to an increased efflux of $\mathrm{Ca}^{2+}$. Instead, with $\mathrm{Na}_{i}^{+}$accumulation, which might occur during hypoxia, the activation would further facilitate $\mathrm{Ca}_{\mathrm{i}}^{2+}$ loading into the myocardial cell. Tissue $\mathrm{pH}$ is another factor that affects the translocation rate of the exchanger (58). The sudden reversal from the acidotic condition to the transient alkalinization at reoxygenation may synergistically support the role of free radicals. Although such a $\mathrm{pH}$ change in hypoxia/reoxygenation studies might be modest, this factor could play a much more significant role in the setting of ischemia and reperfusion.

Accumulated studies indicated that the stoichiometry of $\mathrm{Na}^{+} / \mathrm{Ca}^{2+}$ exchange in cardiac and nervous tissues in various species is most probably $3 \mathrm{Na}^{+}: 1 \mathrm{Ca}^{2+}(17,23,45,55)$. We think it is reasonable to apply this stoichiometry to the analyses of our results from the ferret myocardium. However, two parameters, $k_{\mathrm{NaCa}}$ and $r$, in the equation may vary among species. As discussed above, our analyses did not require knowledge of the absolute scale of the exchange current. Accordingly, the value of $k_{\mathrm{NaCa}}$ was assessed as a ratio for the control level. The values of $r$ were reported as $0.28-0.36$ in studies of guinea-pig myocytes $(17,23,24)$. We tested the effect of varying $r$ value in a wider range of $0.10-0.50(23)$; however, the shift of $r$ in this range did not alter our findings presented in Fig. 4 (data not shown). Furthermore, using the right ventricular papillary muscles from the guinea-pig $(n=5)$, we confirmed that the similar pattern of biphasic $\mathrm{Ca}_{i}^{2+}$ transient was reproducibly observed by the same combination of pharmacological treatment, although the $\mathrm{Ca}_{\mathrm{i}}^{2+}$ transient (peak $\mathrm{Ca}_{\mathrm{i}}^{2+}, 0.8 \pm 0.2 \mu \mathrm{M}$; time to the end of $\mathrm{Ca}_{i}^{2+}$ ascent, $984 \pm 64 \mathrm{~ms}$ ) and the action potential (duration to $80 \%$ regression, $1,032 \pm 91 \mathrm{~ms}$ ) appeared to be more prolonged than those observed in the ferret preparation (Table I). Taken together, quantitative characteristics of the $\mathrm{Na}^{+} / \mathrm{Ca}^{2+}$ exchange current in the ferret ventricle should await future studies using the isolated single cell preparation; however, the difference between the ferret versus guinea-pig, if any, will probably not affect our conclusions.

By a combination of pharmacological interventions, we modulated the subcellular functions of isolated ferret papillary muscle, in which the $\mathrm{SR}$ and the slow $\mathrm{Ca}^{2+}$ channels were blocked and $\mathrm{Na}^{+} / \mathrm{Ca}^{2+}$ exchange was made to operate in the direction of $\mathrm{Ca}^{2+}$ loading throughout the depolarization period. Despite these modulations, all measurements of $\mathrm{Ca}_{i}^{2+}$ transients, tension traces, and the action potentials, showed a pattern of change during hypoxia and reoxygenation that was consistent with control preparations $(19,32)$. The tension trace especially, which represents the final outcome of the E-C coupling process, showed a significant decrease in peak values with an abbreviated time course during hypoxia. These changes were followed by a slow recovery with a prolonged relaxation during reoxygenation (62). These findings suggest not only that our preparations were affected by hypoxia and reoxygenation but also that the subcellular functions remaining after drug intervention were much more essential as targets of hypoxia/reoxygenation than the functions deleted by it. Hence, the role of $\mathrm{Na}^{+} / \mathrm{Ca}^{2+}$ exchange for $\mathrm{Ca}^{2+}$ influx and its modulation during reoxygenation presented in this study could not be interpreted as unusual findings under a specific pharmacological condition. Of interest, while the durations of $\mathrm{Ca}_{i}^{2+}$ transients were abbreviated by the transition from hypoxia to reoxygenation, tension relaxation was prolonged after reoxygenation $(19,32,62)$. This discrepancy between $\mathrm{Ca}_{\mathrm{i}}^{2+}$ and tension time courses, however, is consistent with observations in previous hypoxia/reoxygenation studies in the intact ferret papillary muscle using aequorin $(19,21)$ or in the isolated rat single myocyte loaded with indo-1 (31). Our data also provide evidence that the impaired relaxation that occurs during reoxygenation develops without SR dysfunction or other $\mathrm{Ca}_{i}^{2+}$ handling disturbances. A reasonable conclusion from these studies is that the cause of tension prolongation during reoxygenation and reperfusion resides down-stream from $\mathrm{Ca}_{i}^{2+}$ handling; namely, in the process of cross-bridge cycling (31).

\section{Acknowledgments}

We thank Dr. Yasunori Momose for his helpful advise on action potential recordings. Aequorin was purchased from the laboratory of Dr. J. R. Blinks, Friday Harbor, WA. DPI 201-106 and DCB were generously supplied by Sandoz Ltd., Basel, Switzerland, and Merck Sharp \& Dohme, Rahway, NJ, respectively.

This study was supported in part by Japan Heart Foundation, Yokoyama Foundation, and grant-in-aids from the Ministry of Education, Culture, and Science of Japan (02770482, 03770485) to Dr. Kihara; by National Institutes of Health grant HL-31117, and a Research Career Development Award (HL-01611) to Dr. Morgan.

\section{References}

1. Kihara, Y., W. Grossman, and J. P. Morgan. 1989. Direct measurement of changes in intracellular calcium transients during hypoxia, ischemia, and reperfusion of the intact mammalian heart. Circ. Res. 65:1029-1044.

2. Lee, H. C., R. Mohabir, N. Smith, M. R. Franz, and W. T. Clusin. 1987. Cytosolic calcium transients from the beating mammalian heart. Proc. Natl. Acad. Sci. USA. 84:7793-7797.

3. Steenbergen, C., E. Murphy, L. Levy, and R. E. London. 1987. Elevation in cytosolic free calcium in myocardial ischemia in perfused rat heart. Circ. Res. 60:700-707.

4. Marban, E., M. Kitakaze, H. Kusuoka, J. K. Porterfield, D. T. Yue, and V. P. Chacko. 1987. Intracellular free calcium concentration measured with ${ }^{19} \mathrm{~F}$ NMR spectroscopy in intact ferret hearts. Proc. Natl. Acad. Sci. USA. 84:60056009.

5. Kihara, Y., and J. P. Morgan. 1991. Intracellular calcium and ventricular fibrillation. Studies in the aequorin-loaded isovolumic ferret heart. Circ. Res. 68:1378-1389.

6. Marban, E., M. Kitakaze, Y. Koretsune, D. T. Yue, V. P. Chacko, and M. M. Pike. 1990. Quantification of $\left[\mathrm{Ca}^{2+}\right]_{i}$ in perfused hearts. Critical evaluation of the 5 F-BAPTA and nuclear magnetic resonance method as applied to the study of ischemia and reperfusion. Circ. Res. 66:1255-1267.

7. Opie, L. H., and W. A. Coetezee. 1988. Role of calcium ions in reperfusion arrhythmias: relevance to pharmacologic intervention. Cardiovasc. Drugs Ther 2:623-636

8. Tani, M. 1990. Mechanisms of $\mathrm{Ca}^{2+}$ overload in reperfused ischemic myocardium. Annu. Rev. Physiol. 52:543-559.

9. Renlund, D. G., G. Gerstenblith, E. G. Lakatta, W. E. Jacobus, C. H. Kallman, and M. L. Weisfeldt. 1984. Perfusate sodium during ischemia modifies post-ischemic function and metabolic recovery in the rabbit heart. J. Mol. Cell Cardiol. 16:795-801.

10. Grinwald, P. M., and C. Brosnaham. 1987. Sodium imbalance as a cause of calcium overload in post-hypoxic reoxygenation injury. J. Mol. Cell Cardiol. 19:487-495.

11. Murphy, J. G., T. W. Smith, and J. D. Marsh. 1988. Mechanisms of reoxygenation-induced calcium overload in cultured chick embryo heart cell. Am. J. Physiol. 254:H1133-H1144.

12. Kihara, Y., J. K. Gwathmey, W. Grossman, and J. P. Morgan. 1989. Mechanisms of positive inotropic effects and delayed relaxation produced by DPI 201-106 in mammalian working myocardium: effects on intracellular calcium handling. Br. J. Pharmacol. 96:927-939.

13. Kihara, Y., and J. P. Morgan. 1989. A comparative study of three methods for intracellular loading of the calcium indicator aequorin in ferret papillary muscles. Biochem. Biophys. Res. Commun. 162:402-407. 
14. Gwathmey, J. K., M. T. Slawsky, G. M. Briggs, and J. P. Morgan. 1988 Role of intracellular sodium in the regulation of intracellular calcium and contractility: effects of DPI 201-106 on excitation-contraction coupling in human ventricular myocardium. J. Clin. Invest. 82:1592-1605.

15. Scholtysik, G., R. Salzmann, R. Berhold, J. W. Hertiz, U. Quast, and R. Markstein. 1985. DPI 201-106, a novel cardioactive agent. Combination of cAMP-independent positive inotropic negative chronotropic, action potentia prolonging and coronary dilatory properties. Naunyn Schmiedebergs Arch. Pharmacol. 329:316-325.

16. Barcenas-Ruiz, L., D. J. Beuckelmann, and W. G. Wier. 1987. Sodiumcalcium exchange in heart: membrane currents and changes in $\left[\mathrm{Ca}^{2+}\right]_{i}$. Science (Wash. DC). 238:1720-1722.

17. Beuckelmann, D. J., and W. G. Wier. 1989. Sodium-calcium exchange in guinea-pig cardiac cells: exchange current and changes in intracellular $\mathrm{Ca}^{2+} . J$. Physiol. (Lond.). 414:499-520.

18. Guarnieri, T. 1987. Intracellular sodium-calcium dissociation in early contractile failure in hypoxic ferret papillary muscles. J. Physiol. (Lond.) 388:449-465.

19. MacKinnon, R., J. K. Gwathmey, and J. P. Morgan. 1987. Differential effects of reoxygenation on intracellular calcium and isometric tension. Pflügers Arch. Eur. J. Physiol. 409:448-453.

20. Yue, D. T., E. Marban, and W. G. Wier. 1986. Relationship between force and intracellular $\left[\mathrm{Ca}^{2+}\right]$ in tetanized mammalian heart muscle. J. Gen. Physiol. 87:223-247.

21. Hajjar, R. J., and J. K. Gwathmey. 1990. Direct evidence of changes in myofilament responsiveness to $\mathrm{Ca}^{2+}$ during hypoxia and reoxygenation in myocardium. Am. J. Physiol. 259:H784-H795.

22. Morgan, J. P., W. G. Wier, P. Hess, and J. R. Blinks. 1983. Influence of $\mathrm{Ca}^{++}$-channel blocking agents on calcium transients and tension development in isolated mammalian heart muscle. Circ. Res. 52(Suppl. I):47-52.

23. Kimura, J., S. Miyatake, and A. Noma. 1987. Identification of sodiumcalcium exchange current in single ventricular cells of guinea-pig. J. Physiol (Lond.). 384:199-222.

24. Lipp, P., and L. Pott. 1988. Voltage dependence of sodium-calcium exchange current in guinea-pig atrial myocytes determined by means of an inhibitor. J. Physiol. (Lond.). 403:355-366.

25. Siegl, P. K. S., E. J. Cragoe, M. J. Trumble, and G. J. Kaczorowski. 1984. Inhibition of $\mathrm{Na}^{+} / \mathrm{Ca}^{2+}$ exchange in membrane vesicle and papillary muscle preparations from guinea pig heart by analogs of amiloride. Proc. Natl. Acad. Sci. USA. 81:3238-3242.

26. Leblanc, N., and J. R. Hume. 1990. Sodium current-induced release of calcium from cardiac sarcoplasmic reticulum. Science (Wash. DC). 248:372376.

27. Kawano, S., and R. L. DeHaan. 1990. Analysis of the T-type calcium channel in embryonic chick ventricular myocytes. J. Membr. Biol. 116:9-17.

28. Tytgat, J., J. Vereecke, and E. Carmeliet. 1990. A combined study of sodium current and T-type calcium current in isolated cardiac cells. Pflügers Arch. Eur. J. Physiol. 417:142-148.

29. Eskinder, H., N. J. Rusch, F. D. Supan, J. P. Kampine, and Z. J. Bosnjak. 1991. The effects of volatile anesthetics on L- and T-type calcium channe currents in canine cardiac Purkinje cells. Anesthesiology. 74:919-926.

30. Bean, B. P. 1989. Types of calcium channels in heart muscle. In Molecula and Cellular Mechanisms of Antiarrhythmic Agents. L. Hondeghem, editor. Futura Publishing, Mt. Kisco, New York. 101-111.

31. Silverman, H. S., M. Ninomiya, P. S. Blank, O. Hano, H. Miyata, H. A Spurgeon, E. G. Lakatta, and M. D. Stern. 1991. A cellular mechanism for im paired posthypoxic relaxation in isolated cardiac myocytes: altered myofilamen relaxation kinetics at reoxygenation. Circ. Res. 69:196-208.

32. Allen, D. G., and C. H. Orchard. 1983. Intracellular calcium concentration during hypoxia and metabolic inhibition in mammalian ventricular muscle J. Physiol. (Lond.). 339:107-122.

33. Pike, M. M., M. Kitakaze, and E. Marban. $1990 .{ }^{23}$ Na-NMR measurements of intracellular sodium in intact perfused ferret hearts during ischemia and reperfusion. Am. J. Physiol. 259:H1767-H1773.

34. Ziegelstein, R. C., J. L. Zweier, E. D. Mellits, A. Younes, E. G. Lakatta, M. D. Stern, and H. S. Silverman. 1992. Dimethylthiourea, an oxygen radica scavenger, protects isolated cardiac myocytes from hypoxic injury by inhibition of $\mathrm{Na}^{+}-\mathrm{Ca}^{2+}$ exchange and not by its antioxidant effects. Circ. Res. 70:804-811.

35. Weiss, R. G., E. G. Lakatta, and G. Gerstenblith. 1990. Effects of amiloride on metabolism and contractility during reoxygenation in perfused rat hearts. Circ. Res. 66:1012-1022.

36. Balke, C. W., and W. G. Wier. 1991. Ryanodine does not affect calcium current in guinea pig ventricular myocytes in which $\mathrm{Ca}^{2+}$ is buffered. Circ. Res. 68:897-902.

37. Wier, W. G., and D. T. Yue. 1986. Intracellular calcium transients underlying the short-term force-interval relationship in ferret ventricular myocardium. J. Physiol. (Lond.). 376:507-530.

38. Lederer, W. J., E. Niggli, and R. W. Hadley. 1990. Sodium-calcium exchange in excitable cells: fuzzy space. Science (Wash. DC). 248:283.

39. Crespo, L. M., C. J. Grantham, and M. B. Cannell. 1990. Kinetics, stoichi- ometry and role of the $\mathrm{Na}-\mathrm{Ca}$ exchange mechanism in isolated cardiac myocytes. Nature (Lond.). 345:618-621.

40. Bridge, J. H., J. R. Smolley, and K. W. Spitzer. 1990. The relationship between charge movements associated with $\mathrm{I}_{\mathrm{Ca}}$ and $\mathrm{I}_{\mathrm{Na}-\mathrm{Ca}}$ in cardiac myocytes. Science (Wash. DC). 248:376-378.

41. Earm, Y. E., W. K. Ho, and I. S. So. 1990. Inward current generated by $\mathrm{Na}-\mathrm{Ca}$ exchange during the action potential in single atrial cells of the rabbit. Proc. $R$. Soc. Lond. B240:61-81.

42. Egan, T. M., D. Noble, S. J. Noble, T. Powell, A. J. Spindler, and V. W. Twist. 1989. Sodium-calcium exchange during the action potential in guinea-pig ventricular cells. J. Physiol. (Lond.). 411:639-661.

43. DiFrancesco, D., and D. Noble. 1985. A model of cardiac electrical activity incorporating ionic pumps and concentration changes. Philos. Trans. R. Soc. B 307:353-398.

44. Wier, W. G. 1990 . Cytoplasmic $\left[\mathrm{Ca}^{2+}\right]$ in mammalian ventricle: dynamic control by cellular processes. Annu. Rev. Physiol. 52:467-485.

45. Giles, W., and Y. Shimoni. 1989. Comparison of sodium-calcium exchanger and transient inward currents in single cells from rabbit ventricle. $J$. Physiol. (Lond.). 417:465-481.

46. Earn, Y. E., W. K. Hoo, and I. S. So. 1990. Inward current generated by $\mathrm{Na}-\mathrm{Ca}$ exchange during the action potential in single atrial cells of the rabbit. Proc. R. Soc. Lond. B240:61-81.

47. MacLeod, K. T. 1989. Effects of hypoxia and metabolic inhibition on the intracellular sodium activity of mammalian ventricular muscle. J. Physiol. (Lond.). 416:455-468

48. Bridge, J. H., K. W. Spitzer, and P. R. Ershler. 1988. Relaxation of isolated ventricular cardiomyocytes by a voltage-dependent process. Science (Wash. DC). 241:823-825.

49. Fabiato, A. 1983. Calcium-induced release of calcium from the cardiac s.r. Am. J. Physiol. 245:C1-C14.

50. McMillin-Wood, J., P. E. Workowicz, A. Chu, C. A. Tate, M. A. Goldstein, and M. L. Entman. 1980. Calcium uptake by two preparations of mitochondria from heart. Biochim. Biophys. Acta. 591:251-265.

51. Kohmoto, O., K. W. Spitzer, M. A. Movsesian, and W. H. Barry. 1990. Effects of intracellular acidosis on $\mathrm{Ca}_{i}^{2+}$ transients, transsarcolemmal $\mathrm{Ca}^{2+}$ fluxes, and contraction in ventricular myocytes. Circ. Res. 66:622-632.

52. Orchard, C. H., S. R. Houser, A. A. Kort, A. Bahinski, M. C. Capogrossi, and E. G. Lakatta. 1987. Acidosis facilitates spontaneous sarcoplasmic reticulum $\mathrm{Ca}^{2+}$ release in rat myocardium. J. Gen. Physiol. 90:145-165.

53. Allen, D. G., J. A. Lee, and G. L. Smith. 1989. The consequences of simulated ischaemia on intracellular $\mathrm{Ca}^{2+}$ and tension in isolated ferret ventricular muscle. J. Physiol. (Lond.). 410:297-323.

54. Bers, D. M., and J. H. Bridge. 1989. Relaxation of rabbit ventricular muscle by Na-Ca exchange and sarcoplasmic reticulum calcium pump: ryanodine and voltage sensitivity. Circ. Res. 65:334-342.

55. Miura, Y., and J. Kimura. 1989. Sodium-calcium exchange current. Dependence on internal $\mathrm{Ca}$ and $\mathrm{Na}$ and competitive binding of external $\mathrm{Na}$ and $\mathrm{Ca}$. J. Gen. Physiol. 93:1129-1145.

56. Murphy, E., M. Periman, R. E. London, and C. Steenbergen. 1991. Amiloride delays the ischemia-induced rise in cytosolic free calcium. Circ. Res. 68:1250-1258.

57. Reeves, J. P., C. A. Bailey, and C. C. Hale. 1986. Redox modification of sodium-calcium exchange activity in cardiac sarcolemmal vesicles. J. Biol. Chem. 261:4948-4955.

58. Sheu, S. S., and M. P. Blaustein. 1986. Sodium/calcium exchange and regulation of cell calcium and contractility in cardiac muscle, with a note about vascular smooth muscle. In The Heart and Cardiovascular System. H. A. Fozzard, E. Haber, R. B. Jennings, and A. M. Katz, editors. Raven Press, New York. 509-535.

59. Marklund, S. L. 1988. Role of toxic effects of oxygen in reperfusion damage. J. Mol. Cell Cardiol. 20(Suppl.II):23-30.

60. Kako, K. J. 1987. Free radical effects on membrane protein in myocardial ischemia/reperfusion injury. J. Mol. Cell Cardiol. 19:209-211.

61. Kramer, J. H., I. T. Mark, and W. B. Weglicki. 1984. Differential sensitivity of canine cardiac sarcolemmal and microsomal enzymes to inhibition by free-radical-induced lipid peroxidation. Circ. Res. 55:120-124.

62. Bing, O. H. L., J. F. Keefe, M. J. Wolk, L. J. Finkelstein, and H. J. Levine. 1971. Tension prolongation during recovery from myocardial hypoxia. J. Clin. Invest. 50:660-666.

63. Konishi, M., and S. Kurihara. 1993. Radial spread of aequorin $\mathrm{Ca}^{2+}$ signal in single frog skeletal muscle fibers. Mol. Cell Biochem. 119:59-66.

64. Wier, W. G., M. B. Cannell, J. R. Berlin, E. Marban, and W. J. Lederer. 1987. Cellular and subcellular heterogeneity of $\left[\mathrm{Ca}^{2+}\right]_{i}$ in single heart cells revealed by Fura-2. Science (Wash. DC). 235:325-328.

65. Lakatta, E. G. 1992. Functional implications of spontaneous sarcoplasmic reticulum $\mathrm{Ca}^{2+}$ release in the heart. Cardiovasc. Res. 26:193-214.

66. Langer, G. A., and T. L. Rich. 1992. A discrete Na-Ca exchange-dependent Ca compartment in rat ventricular cells: exchange and localization. Am. J. Physiol. 262:C1149-C1153. 